\title{
PASTORALNO-TEOLOGICZNE PODSTAWY KATECHEZY SAKRAMENTALNEJ OSÓB Z NIEPEŁNOSPRAWNOŚCIĄ INTELEKTUALNĄ
}

\section{WSTĘP}

Autorzy Deklaracji o wychowaniu chrześcijańskim Gravissimum educations (DWCH) wskazali, że każdy człowiek - bez względu na rasę, stan oraz wiek posiada nienaruszalne prawo do wychowania. Ów proces winien być dostosowany do wrodzonych zdolności człowieka, a także różnicy płci, kultury oraz ojczystych tradycji. Jego zaś celem jest zbawienie człowieka oraz jego integracja ze społeczeństwem w duchu braterskiej jedności i odpowiedzialności (DWCH 1). W ramach wszechstronnego rozwoju każdy ochrzczony podsiada również prawo do wychowania chrześcijańskiego. Jest ono ukierunkowane m.in. na wprowadzanie człowieka $\mathrm{w}$ tajemnicę zbawienia, pogłębienie wiary oraz uwielbienie Boga poprzez kult liturgiczny (DWCH 2). Prawo to - jako niezbywalne - obejmuje również osoby z niepełnosprawnością intelektualną.

Niemniej jednak wśród duszpasterzy i katechetów, a także samych rodziców pojawiają się wątpliwości: czy osoby z niepełnosprawnością intelektualną mogą przyjmować sakramenty; czy rozumieją różnicę między dobrem a złem, a zatem jak je spowiadać; jak zweryfikować ich wiarę. Wątpliwości te wynikają z jednej strony ze zbyt przeintelektualizowanego charakteru katechezy przygotowującej osoby zdrowe do przyjęcia sakramentów, nieznajomości podstaw pedagogiki specjalnej, a przede wszystkim z braku świadomości, że niepełnosprawność

Ks. dr ŁUKASZ NYCZ - Katedra Katechetyki Integralnej, Instytut Teologii Pastoralnej i Katechetyki, Wydział Teologii Katolickiego Uniwersytetu Lubelskiego Jana Pawła II; Al. Racławickie 14, 20-950 Lublin; e-mail: nyczlukasz@gmail.com 
intelektualna nie oznacza niepełnosprawności duchowej. Stąd też wynika potrzeba ukazania argumentacji teologiczno-pastoralnej wskazującej nie tylko na możliwość, ale wręcz konieczność katechezy sakramentalnej osób z niepełnosprawnością intelektualną.

Niniejsze rozważania na temat katechezy sakramentalnej zostaną zawężone do przygotowania do dwóch sakramentów inicjacji chrześcijańskiej - Eucharystii i bierzmowania, z uwagi na fakt, że trzeci - chrzest - zdecydowana większość dzieci przyjmuje w okresie niemowlęcym. Badania zostaną jednak poszerzone o przygotowanie do sakramentu pokuty i pojednania, gdyż warunkiem przystąpienia do przyjęcia Komunii Świętej, jak i sakramentu bierzmowania jest stan łaski sakramentalnej. W treści artykułu zostaną najpierw przedstawione wskazania dokumentów katechetycznych, a następnie uwarunkowania teologiczno-prawne podjęcia i realizacji katechezy sakramentalnej osób z niepełnosprawnością intelektualną.

\section{UWARUNKOWANIA PASTORALNE}

Wskazania dotyczące możliwości przekazu wiary, uczestnictwa osób z niepełnosprawnością intelektualną w Eucharystii, a także dotyczące ich przygotowania do sakramentów pokuty i pojednania oraz bierzmowania można odnaleźć zarówno w dokumentach Kościoła powszechnego, jak również w promulgowanych przez Konferencje Episkopatu Polski i biskupów diecezjalnych.

\subsection{DOKUMENTY KATECHETYCZNE KOŚCIOŁA POWSZECHNEGO}

Pierwszym posoborowym dokumentem, kształtującym przez długie lata posługę katechetyczną wobec osób z niepełnosprawnością intelektualną, była Ogólna instrukcja katechetyczna (OIK). Jej autorzy wskazali, że inspiracją do tego typu działań katechetycznych jest sama Ewangelia, w której Jezus ukazał wielki szacunek Boga względem człowieka, gdy poprzez dokonywane cuda wskazał na konieczność pomocy potrzebującym. W ten sposób wyraźnie została podkreślona niezbywalna godność i podmiotowość osoby ludzkiej, także chorej oraz posiadającej pewne ograniczenia w funkcjonowaniu (OIK 65-66). Jako cel katechizacji osób z niepełnosprawnością zostało uwzględnione podjęcie przez nich życia wiary zgodnie z ich możliwościami (OIK 91).

Zagadnienie katechezy osób z niepełnosprawnością intelektualną było jednym z tematów obrad synodu biskupów w Rzymie w 1977 r. poświęconego kate- 
chizacji. Ojcowie soborowi wskazali na konieczność uwzględnienia w procesie katechetycznym specyfiki funkcjonowania tych osób. Za cel katechizacji uznali przekazanie radości życia wynikającej z nieskończonej miłości Boga. Ponadto biskupi zebrani na synodzie wskazali wyraźnie, że osoby z niepełnosprawnością, jako członkowie wspólnoty parafialnej, winni zostać przygotowani do przyjęcia sakramentów, a także uczestnictwa w liturgii i nabożeństwach, które jednocześnie powinny być dostosowane do ich możliwości (Jucha, 2001, s. 54).

Pokłosiem omawianego synodu biskupów była adhortacja apostolska św. Jana Pawła II Catechesi tradendae (CT). Papież podkreślił w niej wyraźnie, że każdy ochrzczony ma niezaprzeczalne prawo do otrzymania pełnej nauki chrześcijańskiej. Jednocześnie stanowczo wystąpił przeciwko jakiejkolwiek dyskryminacji w tej materii (CT 14). Wyraził to wprost słowami: „Myślę tu najpierw o wszystkich upośledzonych fizycznie lub umysłowo. Mają oni prawo tak samo jak ich rówieśnicy poznać tajemnice wiary” (CT 41). Św. Jan Paweł II wskazał ponadto, że w procesie katechetycznym należy stosować zarówno metody, jak i język dostosowane do możliwości odbiorców. Jednak nie może to odbywać się kosztem integralności nauczania prawd wiary (CT 31). Docenił również starania wychowawców i stowarzyszeń pracujących z osobami z niepełnosprawnością intelektualną, zaznaczając, że większy trud, który wiąże się z ich pracą, pomnaża zdobywane zasługi (CT 41).

Pokłosiem obrad omawianego synodu biskupów oraz adhortacji Catechesi tradendae było opracowanie Dyrektorium ogólnego o katechizacji (DOK). Autorzy dokumentu wskazali, że celem katechezy jest nie tylko spotkanie z Jezusem, ale także doprowadzenie katechizowanych do zjednoczenia i głębokiej zażyłości z Nim (DOK 80). We współczesnej katechezie nie chodzi więc już tylko i wyłącznie o intelektualne poznanie Chrystusa, ale o budowanie z Nim głębokiej relacji. Tak postawiony cel katechezy pozwala uczestniczyć w niej osobie z niepełnosprawnością intelektualną na równych prawach z innymi członkami Kościoła (Kiciński, 2008).

Szczegółowe kwestie dotyczące katechezy osób z niepełnosprawnością intelektualną zostały zapisane przez autorów dokumentu w jego czwartej części poświęconej adresatom katechezy (DOK 163-214). Bezpośrednio katechezie specjalnej został poświęcony tylko jeden punkt. W świetle jego zapisu każda osoba - bez względu na swoje ograniczenia - ,jest zdolna do wzrostu w świętości” (DOK 189). Ponadto, zostało wyraźnie podkreślone, że katecheza specjalna nie może być marginalizowana. Jej przestrzenią winno stać się środowisko 
rodziny oraz parafii. Sami katecheci powinni zaś pogłębiać swoją wiedzę z zakresu pedagogiki specjalnej (DOK 189).

\subsection{DOKUMENTY KATECHETYCZNE KOŚCIOŁA W POLSCE}

Zanim zostanie omówione Dyrektorium katechetyczne Kościoła katolickiego w Polsce, które powstało jako odpowiedź na wskazania Dyrektorium ogólnego o katechizacji, należy wspomnieć o jeszcze jednym dokumencie, który wpłynął na kształt katechezy specjalnej w Polsce, a mianowicie o uchwałach II Polskiego Synodu Plenarnego (1991-1999) (PSP). Prawodawca poświęcił omawianym zagadnieniom tylko jeden punkt. Przypomniał w nim, że w świetle Kodeksu prawa kanonicznego odpowiedzialny za organizację katechezy osób z niepełnosprawnością jest proboszcz. Przestrzenią zaś jej realizacji winna być, w pierwszym rzędzie, wspólnota parafialna, która nie tylko w ten sposób realizuje ewangeliczne wezwanie do postawy miłości i miłosierdzia, ale sama przez to rozwija się i ubogaca (PSP, s. 59-60).

Równie mało miejsca poświęcili katechezie specjalnej autorzy Dyrektorium katechetyczne Kościoła katolickiego w Polsce (PDK). Miejscem formacji katechetycznej osób z niepełnosprawnością, w świetle zapisów omawianego dokumentu, jest wspólnota parafialna. Ponadto przestrzenią dla katechezy winna stać się rodzina, a także szkoła. Wymaga to jednak odpowiedniego przygotowania katechetów poprzez wprowadzenie do programu studiów wykładów i ćwiczeń z katechezy specjalnej (PDK 109), zarówno na uniwersytetach jak i w seminariach duchownych. $\mathrm{O}$ taką formację katechetów powinny również zadbać diecezjalne ośrodki katechetyczne (PDK 156).

Problematyka katechezy specjalnej w omówionych dokumentach pozostawała raczej na poziomie ogólnych dyrektyw, aniżeli konkretnych wskazań katechetyczno-metodycznych. Zostały one jednak szczegółowo zawarte w Podstawie programowej katechezy Kościoła katolickiego w Polsce (PPK) oraz Programie nauczania religii rzymskokatolickiej w przedszkolach i szkołach (PNR).

Autorzy Podstawy programowej katechezy Kościoła katolickiego w Polsce poświęcili zagadnieniom katechezy specjalnej szósty rozdział dokumentu. Jako adresatów tego typu katechezy wskazali osoby z niepełnosprawnością intelektualną oraz z niedomaganiami słuchu i wzroku (PPK 2001). Podobnie jak w przypadku katechezy dzieci i młodzieży w normie intelektualnej zostały określne cele, zadania, treści oraz osiągnięcia uczniów. Zostały one poprzedzone ogólną charakterystyką osób z niepełnosprawnością intelektualną oraz charakterystyką katechezy 
osób z niedomaganiami słuchu i osób niewidzących. W dokumencie znalazły się również informacje dotyczące procedury osiągania celów, jak i współpracy środowisk wychowawczych (PPK 2001).

Autorzy, wskazując na założenia ogólne dotyczące procesu katechetycznego, wyraźnie podkreślili potrzebę indywidualnego podejścia do każdego ucznia oraz potrzebę ustalenia osiągnięć, którymi powinien wykazać się on na poszczególnych etapach edukacyjnych. Podkreślili także, że w ostatecznej ocenie nie liczy się stopień wiedzy, a wewnętrzne nastawienie ucznia do treści ewangelicznych i osoby Jezusa Chrystusa. Osoba z niepełnosprawnością poprzez katechezę ma spotkać kochającego i zatroskanego Boga, co realizuje się przede wszystkim w modlitwie i liturgii. Winna ona odkryć również swoje miejsce we wspólnocie rodzinnej, szkolnej i parafialnej i zaangażować się w nich poprzez życie zgodne z przykazaniem miłości (Chałupniak, 2003).

Zrealizowanie opisanych celów będzie możliwe jedynie przy współpracy środowisk wychowawczych. $Z$ jednej strony, wiara to nie sama wiedza, ale przede wszystkim ma ona przełożenie na kształtowanie postawy wobec drugiego człowieka. $\mathrm{Z}$ drugiej zaś, mniejsze możliwości poznawcze osób z niepełnosprawnością intelektualną przekładają się na potrzebę większego zaangażowania osób za nie odpowiedzialnych. Ze strony rodziców jest to otwarcie na pomoc parafii i instytucji charytatywnych. Do obowiązków parafii należy zaś: pomoc w rozwoju życia religijnego, prowadzenie katechezy sakramentalnej, organizacji nabożeństw dedykowanych osobom $\mathrm{z}$ niepełnosprawnością, a także zaangażowanie rodzin w duszpasterstwa specjalistyczne (Chałupniak, 2003).

W wyniku reformy edukacji oraz przemian społecznych, kulturowych i religijnych, Konferencja Episkopatu Polski w 2010 r. promulgowała nową wersję Podstawy programowej katechezy Kościoła katolickiego w Polsce (PPK 2010). Podobnie jak w przypadku poprzedniego dokumentu katechezie specjalnej został poświęcony szósty rozdział. Została w nim zawarta przede wszystkim ogólna charakterystyka funkcjonowania osób z niepełnosprawnością intelektualną według poszczególnych stopni tej niepełnosprawności i wskazania dotyczące dostosowania do nich celów katechetycznych. W układzie tabelarycznym zostały zaprezentowane cele dla katechezy osób $\mathrm{z}$ niepełnosprawnością $\mathrm{w}$ stopniu umiarkowanym i znacznym oraz szczegółowe zadania służące ich realizacji. W zakresie treści, stanowiących wymagania szczegółowe, ujęto jedynie wiadomości, gdyż umiejętności w odniesieniu do poszczególnych zadań winny zostać zaplanowane dla uczniów indywidualnie (PPK 2010). 
Za główny cel katechizacji osób z umiarkowaną i znaczną niepełnosprawnością autorzy dokumentu uznali rozwijanie zdolności we wzroście w świętości. W związku z tym winni być oni wprowadzani w życie wspólnoty wierzących, do czego niezbędne jest przyjęcie, jako zasadę życia, przykazania miłości Boga i bliźniego. W procesie katechizacji osoby te winny również odkryć siebie jako dzieci Boże, stworzone na Jego obraz i podobieństwo. Fundamentalnym zaś elementem katechezy na drodze do świętości jest w końcu pełne uczestnictwo w życiu sakramentalnym (PPK 2010). W Podstawie programowej katechezy zostały również zawarte wskazania dotyczące środków dydaktycznych, jak i metod pracy, a także zasady współpracy środowisk wychowawczych, tj. rodziny i parafii. Opisane wskazania zostały uzupełnione o postulaty dotyczące katechezy osób z autyzmem oraz niesłyszących lub słabo słyszących, a także niewidomych i słabowidzących (PPK 2010).

Tak szerokie ujęcie katechezy osób z niepełnosprawnością naukową w ramach Podstawy programowej religii umożliwiło doprecyzowanie zagadnień katechezy specjalnej w Programie nauczania religii rzymskokatolickiej $w$ przedszkolach $i$ szkołach. Prezentowany dokument stanowił jedynie podstawę do tworzenia indywidualnych programów katechetycznych, wynikających z ogromnego zróżnicowania potrzeb osób z niepełnosprawnością intelektualną (Osewska, Stala, 2010).

Zgodnie ze wskazaniami zawartymi w omawianym dokumencie w przypadku katechezy osób z lekką niepełnosprawnością można stosować wybrane programy nauczania religii, które jednak należy dostosować do specyfiki ich funkcjonowania i uwarunkowań psychofizycznych. Autorzy dokumentu wskazali ponadto, aby w jednostkach katechetycznych wychodzić od treści podstawowych, konkretnych oraz obrazowych i stosować przykłady z życia codziennego. Ponadto przy tworzeniu programu katecheta powinien bazować na wiedzy dotyczącej obszarów dobrego funkcjonowania ucznia oraz jego zainteresowań. Katecheci byli również zachęcani do konsultacji działań dydaktyczno-wychowawczych ze specjalistami, takimi jak logopeda, psycholog czy fizjoterapeuta (PNR).

Katecheza uczniów z niepełnosprawnością w stopniu umiarkowanym i znacznym powinna odbywać się według corocznie przygotowywanych indywidualnych programów, które należy także zharmonizować z indywidualnymi programami terapeutyczno-edukacyjnymi. Ze względu na specyfikę tego typu procesu katechetycznego autorzy programu nie określili odrębnych celów, zadań ani treści na kolejnych etapach edukacji, gdyż powinny być one dostosowane do indywidualnego tempa rozwoju każdego dziecka. Programy opracowywane przez katechetów powinny bazować na obowiązującej podstawie programowej oraz na 
ogólnopolskich lub diecezjalnych programach mających charakter ramowy i ogólny, zatwierdzonych jednak przez władzę kościelną (PDK, s. 96).

Autorzy programu powtórzyli zapisy z podstawy programowej dotyczącej procedury realizacji programu oraz zapisu o współpracy środowisk wychowawczych. Dodatkowo w omawianym dokumencie został umieszczony wykaz tematów spotkań realizowanych w ramach duszpasterstwa katechetycznego w parafii (PNR).

W kontekście katechezy sakramentalnej osób z niepełnosprawnością intelektualną nie można nie wspomnieć o orzeczeniach synodów poszczególnych diecezji w Polsce. Podsumowując ich analizę, ks. Andrzej Kiciński zaznaczył, że prawodawcy nie mają wątpliwości, że najlepszą pomocą dla osób z niepełnosprawnością jest katecheza. Podkreślił również, że tylko jeden z Kościołów lokalnych ograniczył osobom z głęboką niepełnosprawnością możliwość przygotowania do Pierwszej Komunii Świętej (Kiciński, 2010).

\section{UWARUNKOWANIA TEOLOGICZNE}

Rozwój troski Kościoła o katechezę osób z niepełnosprawnością przyniósł również pogłębioną refleksję na temat możliwości przystępowania ich do sakramentów pokuty i pojednania, Eucharystii oraz bierzmowania. Pogłębiona refleksja teologiczna oraz praca katechetów zaowocowały tym, że nie mówi się już tylko o możliwości, ale wręcz konieczności inicjacji sakramentalnej osób z niepełnosprawnością, której fundamentem jest przyjęty przez nich chrzest (KKK 1213). Sakramenty stanowią źródło łaski (KKK 1127), która towarzyszy i wspomaga ich na różnych etapach życia (KKK 1210), prowadząc ostatecznie do zbawienia (KKK 1129). Łaska, którą niosą ze sobą sakramenty, jest potrzebna także, a może szczególnie, tym, którzy czasami nie potrafią wyrazić swojej wiary z powodu swojej niepełnosprawności. Dokonuje ona też niejako konsekracji ich cierpienia i stanowi pomoc w jego przeżywaniu (Sosna, 2010).

\subsection{SAKRAMENT POKUTY}

Pierwszymi sakramentami, do których przygotowywane są osoby z niepełnosprawnością intelektualną, są sakramenty pokuty i pojednania oraz Eucharystii. Zgodnie z postanowieniami Kodeksu prawa kanonicznego (KPK), aby móc w pełni uczestniczyć we mszy świętej, należy odbyć sakramentalną spowiedź (KPK kan. 914). „Wierny, aby otrzymać zbawczy środek sakramentu pokuty, powinien 
być tak usposobiony, by odrzucając grzechy, które popełnił, i mając postanowienie poprawy, nawracał się do Boga" (KPK kan. 987). Zwyczajową formą sprawowania sakramentu pokuty i pojednania jest indywidualna i integralna spowiedź. Jedynie niemożliwość fizyczna lub intelektualna umożliwia zastosowanie innej formy pojednania człowieka z Bogiem (KPK kan. 960). Stąd też decyzja o dopuszczeniu osoby z niepełnosprawnością intelektualną do sakramentu pokuty i pojednania zależy od jej zdolności rozróżnienia dobra i zła, a także możliwości komunikacji ze spowiednikiem (Broda, 2015).

Powołując się na badania psychologiczne, można stwierdzić, że u dzieci już w drugim roku życia można zaobserwować zalążki sumienia. Potrafią one odróżnić dobro od zła na podstawie akceptacji lub dezaprobaty dorosłych na podejmowane przez nich działania. Co więcej, osoby z niepełnosprawnością, także w stopniu głębokim, odznaczają się bogactwem potrzeb psychicznych, m.in. miłości i bezpieczeństwa. Stąd też są w stanie wyrazić brak miłości i zaufania, a także zaniepokojenie, które to są skutkiem grzechu zrywającego przyjaźń człowieka z Bogiem i komunię z Kościołem (Kiciński, 2011).

Pomimo wielu uwarunkowań oceny moralnej czynu osoby z niepełnosprawnością intelektualną można przyjąć, że jest ona świadoma tego, co czyni źle. Świadomość ta pojawia się chociażby w momencie, gdy osoba z niepełnosprawnością nie chce wykonać polecenia, gdyż wiązałoby się to z zaprzestaniem czynności przyjemnej. W innym przypadku osoba $z$ niepełnosprawnością choć wie, że może zrobić coś dobrego i umie to zrobić, jednak nie podejmuje tego działania ze względu na coś przyjemnego lub też nie robi nic. Ostatecznie zaś osoba z niepełnosprawnością wie, że robi coś źle, gdyż w analogicznej sytuacji wcześniej dokonała już właściwego wyboru. Ocena czynu moralnego, w przypadku omawianej grupy osób, dokonuje się także na podstawie szkód materialnych lub otrzymanej kary (Jucha, 2002).

$\mathrm{Z}$ opinii katechetów przygotowujących osoby z niepełnosprawnością intelektualną do sakramentu pokuty wynika, że mają one pojęcie grzechu, który rozumieją jako krzywdę wyrządzoną Bogu i ludziom. Uważa się, że skoro mogą one czynić dobro na miarę swojej możliwości, to mogą również popełniać grzechy proporcjonalnie do swojej niepełnosprawności (Jucha, 2002).

Jeżeli chodzi o formę komunikacji ze spowiednikiem podczas spowiedzi, osoby z niepełnosprawnością intelektualną powinny mieć prawo do spowiedzi u księdza znającego alternatywne metody komunikacji (Kiciński, 2011). Prawodawca dopuszcza także możliwość posługi tłumacza, który jest zobowiązanych do zachowania tajemnicy spowiedzi (KPK kan. 938 par. 2). 
Prawodawca w kanonach Kodeksu prawa kanonicznego przewidział również, że w przypadku niemożliwości fizycznej ${ }^{1}$ lub moralnej ${ }^{2}$ daje możliwość innego sposobu pojednania penitenta z Bogiem i Kościołem, czyli np. żalu doskonałego. Niemniej jednak we wszystkich tych przypadkach istnieje konieczność jak najszybszego przystąpienia do spowiedzi, gdy ustaną okoliczności, które usprawiedliwiały jej odłożenie (Rincon-Perez, 2011).

\subsection{PIERWSZA KOMUNIA ŚWIĘTA}

Podobnie jak miało to miejsce w przypadku sakramentu pokuty, Kodeks prawa kanonicznego definiuje warunki, jakie powinna spełnić osoba, przystępując do Komunii Świętej. Prawodawca określił, że: „Każdy ochrzczony, jeśli tylko prawo tego nie zabrania, może i powinien być dopuszczony do Komunii Świętej” (KPK kan. 912). Dzieci mogą być zaś dopuszczone do Komunii, jeśli mają wystarczające rozeznanie, a także zostały odpowiednio przygotowane. Katecheza powinna obejmować zrozumienie tajemnicy Chrystusa, a także umożliwić przyjęcie z wiarą i pobożnością Jego Ciała (KPK kan. 913, par. 1). Jednocześnie prawodawca zezwolił na udzielenie Komunii Świętej dziecku w niebezpieczeństwie śmierci, jednak pod warunkiem, że potrafi ono odróżnić chleb od konsekrowanej hostii, a także przyjąć ją z szacunkiem (KPK kan. 913, par. 2).

Jeżeli chodzi o pierwsze kryterium, jakim jest „wiek rozeznania”, prawodawca ustalił jego dolną granicę na siedem lat. Jednocześnie jednak użyte w kanonie sformułowanie „domniemywa się” wskazuje na to, że nie decyduje tu tylko i wyłącznie wiek, ale sama umiejętność rozeznania, którą dziecko może osiągnąć zarówno wcześniej, jak i później. Zasadę tę można odnieść do osób z niepełnosprawnością. Można dopuścić je do Komunii Świętej, wraz z zdrowymi rówieśnikami, upewniając się jedynie, czy mają faktyczne umiejętności, które pozwalają odróżnić Chleb eucharystyczny od zwykłego chleba (Sosna, 2007).

Za udzielaniem Komunii Świętej osobom z niepełnosprawnością intelektualną przemawia także tradycja Kościoła, w myśl której była ona udzielana w pewnym okresie historii także niemowlętom. Ograniczanie do niej dostępu może być także pokłosiem fałszywego myślenia związanego z herezją jansenizmu. Janseniści

\footnotetext{
${ }^{1}$ Przez niemożliwość fizyczną należy rozumieć: ciężką chorobę, brak czasu wobec nieuchronnego niebezpieczeństwa, niemożność mówienia, niezawinioną ignorancję lub zapomnienie.

${ }^{2}$ Przez niemożliwość moralną należy rozumieć: obawę o złamanie tajemnicy spowiedzi, niebezpieczeństwo zgorszenia lub grzechu dla penitenta lub spowiednika, wielkie skrupuły sumienia, niebezpieczeństwo dużych i prawdopodobnych szkód, niebezpieczeństwo infamii poza spowiedzią.
} 
uważali Komunię Świętą za nagrodę. Tymczasem w świetle postanowień Soboru Trydenckiego jest ona lekarstwem i ochroną przed grzechem (Kiciński, 2011).

Kluczowy w prowadzonej dyskusji wydaje się głos papieża Piusa X, który dekretem Kongregacji Sakramentów z 8 sierpnia 1910 r. stwierdził, że osobom z niepełnosprawnością intelektualną: „W niebezpieczeństwie śmierci można udzielić Komunii Świętej, byleby tylko potrafiły ją odróżnić od codziennego chleba. Poza niebezpieczeństwem śmierci wymagać należy od nich dokładniejszego poznania nauki chrześcijańskiej i troskliwego przygotowania, aby mogły zapoznać się przynajmniej z koniecznymi do zbawienia prawdami w ramach ich możliwości poznawczych i z pobożnością właściwą wiekowi dziecięcemu przystąpić do Komunii Świętej" (Lechów, 2014, s. 215).

Posumowaniem całości rozważań dotyczących możliwości udzielania Komunii Świętej osobom z niepełnosprawnością stanowią słowa Benedykta XVI zapisane z adhortacji Sacramentum caritatis (SC): „W końcu, należy również zapewnić Komunię eucharystyczną, na tyle, na ile to jest możliwe, osobom upośledzonym umysłowo, ochrzczonym i bierzmowanym: Otrzymują one Eucharystię w wierze ich rodziny lub wspólnoty, która im towarzyszy” (SC 58).

\subsection{SAKRAMENT BIERZMOWANIA}

Podobnie jak w przypadku sakramentów pokuty i pojednania oraz Eucharystii można spotkać się z opiniami kwestionującymi zasadność udzielania osobom z niepełnosprawnością intelektualną sakramentu bierzmowania. Tymczasem istnieje teologiczne uzasadnienie takiej właśnie praktyki. Wynika ono z jedności między sakramentami chrztu i bierzmowania. W momencie udzielenia sakramentu chrztu człowiek otrzymuje bowiem tylko zadatek darów Ducha Świętego do realizacji drogi wiary w ramach swojego osobistego powołania. To dopiero bierzmowanie wprowadza w pełnię życia chrześcijańskiego. Kościół traktuje chrzest, bierzmowanie i Eucharystię jako jedność (KKK 1212). Nieuzasadnione więc wydaje się być pozbawianie osoby, także z niepełnosprawnością, prawa do pozostałych sakramentów, jeżeli otrzymała chrzest święty (Kurzydło, 2017). Potwierdził to także prawodawca w kanonach Kodeksu prawa kanonicznego, stwierdzając, że: „zdatny do otrzymania bierzmowania jest każdy i tylko ten, kto został ochrzczony, a nie był jeszcze bierzmowany" (KPK kan. 889, par. 1).

Pomimo tak jasnego stanowiska reprezentowanego przez teologów, jak i ujętego w postulatach wynikających z prawa kanonicznego można spotkać się z pytaniami o kwestię „dojrzałości” osób z niepełnosprawnością intelektualną, skoro 
bierzmowanie jest nazywane „sakramentem dojrzałości chrześcijańskiej” (KKK 1308). Należy tu jasno określić, że oczekiwana w tym wypadku „dojrzałość” nie ma nic wspólnego z wiekiem i rozwojem naturalnym. Nie można jej także utożsamiać ze zdolnościami intelektualnymi. Należy natomiast docenić wiarę osoby z niepełnosprawnością intelektualną oraz wspólnoty, która towarzyszy jej w procesie przygotowanie do sakramentu bierzmowania (Sona, 2007).

Bezzasadna wydaje się również argumentacja, w której podkreślano, że osoby, zwłaszcza z głębszą niepełnosprawnością intelektualną, nigdy nie będą samodzielnie mogły uczestniczyć w życiu Kościoła. W opinii katechetów pracujących wśród takich właśnie osób panuje przekonanie, że Bóg wyznaczył im, jak także ich rodzicom, specjalne zadania. Choć może być ono niezrozumiałe dla wielu osób, to jednak nie jest to argument, by odmówić osobom z niepełnosprawnością intelektualną darów Ducha Świętego potrzebnych do realizacji swojego życiowego zadania (Kiciński, 2009).

\section{ZAKOŃCZENIE}

Zarówno dokumenty magisterium Kościoła dotyczące stanowiska odnośnie do katechezy specjalnej, jak i powszechna w Polsce praktyka udzielania osobom z niepełnosprawnością intelektualną sakramentów pokuty i pojednania, Eucharystii i bierzmowania potwierdzają niezbywalną godność tych osób oraz szczególną troskę o nie wspólnoty wierzących. Niemniej jednak stanowi to wyzwanie do poszukiwania metod i środków umożliwiających - zgodne z indywidualnymi możliwościami każdego z katechizowanych - przygotowania ich do przyjęcia wspomnianych sakramentów. Kluczowe zatem powinno być pytanie nie o to, czy osoby te mogą przystąpić do sakramentów pokuty i pojednania, Eucharystii i bierzmowania, ale jak je do nich przygotować?

\section{SKRÓTY UŻYTE W ARTYKULE}

CT

DOK

DWCH
Jan Paweł II. Posynodalna adhortacja apostolska o katechizacji w naszych czasach Catechesi tradendae. 16 października 1979.

Kongregacja ds. Duchowieństwa. Dyrektorium ogólne o katechizacji. 15 sierpnia 1997.

Deklaracja o wychowaniu chrześcijańskim Gravissimum educationis.

28 października 1965. 
KPK Kodeks prawa kanonicznego. 25 stycznia 1983 (27 listopada 1983).

OIK

Kongregacja ds. Duchowieństwa. Ogólna instrukcja katechetyczna Directorium Catechisticum Generale. 11 kwietnia 1971.

PDK Konferencja Episkopatu Polski. Dyrektorium katechetyczne Kościoła katolickiego w Polsce. 20 czerwca 2001.

PNR $2001 \quad$ Konferencja Episkopatu Polski. Program nauczania religii rzymskokatolickiej w przedszkolach $i$ szkołach. 20 czerwca 2001.

PNR $2010 \quad$ Konferencja Episkopatu Polski. Program nauczania religii rzymskokatolickiej w przedszkolach i szkolach. 9 czerwca 2010.

PPK $2001 \quad$ Konferencja Episkopatu Polski. Podstawa programowa katechezy Kościola katolickiego $w$ Polsce. 21 czerwca 2001.

PPK $2010 \quad$ Komisja Wychowania Katolickiego Konferencji Episkopatu Polski. Podstawa programowa katechezy Kościoła katolickiego w Polsce. 9 czerwca 2010.

PSP II Polski Synod Plenarny 1991-1999.

SC Benedykt XVI. Posynodalna adhortacja apostolska o Eucharystii, źródle i szczycie życia i misji Kościoła Sacramentum caritatis. 22 lutego 2007.

\section{BIBLIOGRAFIA}

BENEDYKT XVI (2007). Posynodalna adhortacja apostolska o Eucharystii, źródle i szczycie życia i misji Kościoła Sacramentum caritatis, 22 lutego. Watykan.

Broda, M. (2015). Katecheza specjalna a formacja sumienia. W: R. CEGlareK, M. SzTABA (red.), Być czlowiekiem sumienia. Interdyscyplinarny namyst nad fenomenem sumienia (s. 275-289). Częstochowa: Wydawnictwo Archidiecezjalne Regina Poloniae.

ChalupNiAK, R. (2003). Katecheza specjalna - w centrum czy na marginesie działalności katechetycznej Kościoła? W: J. Stala (red.), Katecheza specjalna dzisiaj. Problemy i wyzwania (s. 13-26). Kielce: Jedność.

II Polski Synod Plenarny 1991-1999 (2001). Poznań: Pallotinum.

JAN PAWEe II (1979). Posynodalna adhortacja apostolska o katechizacji w naszych czasach Catechesi tradendae, 16 października. Watykan.

JuCHA, D. (2002). Sakrament pokuty oraz I Komunia Święta osób upośledzonych umysłowo. W: J. Stala (red.), Dzisiejszy katecheta. Stan aktualny i wyzwania (s. 339-370). Kraków: WAM.

JuCHA, D. (2008). Katecheza sakramentalna osób z niepełnosprawnością intelektualną. W: A. KICIŃSKI (red.), Katecheza osób szczególnej troski. Stan aktualny propozycje na przyszłość (s. 52-64). Kraków: WAM.

KICIŃSKI, A. (2008). Moc Słowa Bożego. Podstawy teologiczne katechezy osób z niepełnosprawnością intelektualną. W: H. SŁOTwIŃSKA (red.), Obecność Biblii w katechezie (s. 195-210). Lublin: Gaudium.

KICIŃSKI, A. (2009). Katecheza przed bierzmowaniem osób z niepełnosprawnością intelektualną. Roczniki Liturgiczne, 1(56), 181-191.

KiCiŃSKI, A. (2012). Synod - Niepełnosprawni - Eucharystia. W: M. CZUBAK, B. KondRACKA, M. PALUSZKIEWICZ (red.), Posłuszeństwo Ewangelii - Eucharystia (s. 547-560). Siedlce: Unitas. 
KICIŃSKI, A. (2011). Katecheza osób z niepetnosprawnościq intelektualna w Polsce po Soborze Watykańskim II. Lublin: Wydawnictwo KUL.

Kodeks prawa kanonicznego (2008). Poznań: Pallotinum.

Komisja Wychowania Katolickiego Konferencji EPISKOPATU POLSKI (2001). Program nauczania religii rzymskokatolickiej $w$ szkołach.

Komisja Wychowania Katolickiego Konferencji EPISKOPATU POLSKI (2010). Program nauczania religii.

KONFERENCJA EPISKOPATU POLSKI (2001). Dyrektorium katechetyczne Kościoła katolickiego w Polsce.

Konferencja Episkopatu POLSKI (2001). Podstawa programowa katechezy Kościola katolickiego $w$ Polsce.

Konferencja EPISKOPATU POLSKI (2010). Podstawa programowa katechezy Kościoła katolickiego $w$ Polsce, 8 marca.

KONGREGACJA DS. DuCHOWIEŃSTWA (1997). Dyrektorium ogólne o katechizacji.

KongregaCja DS. Duchowieństwa (1971). Ogólna instrukcja katechetyczna Directorium Catechisticum Generale.

KuRZYDŁo, D. (2017). Bierzmowanie osób niepełnosprawnych intelektualnie. Studia Koszalińsko-Kolobrzeskie, 24, 231-242.

LECHów, W. (2014). Współpraca środowisk katechetycznych w wychowaniu religijnym osób z niepełnosprawnością intelektualną w nowych dokumentach programowych katechezy. Colloquia Theologica Ottoniana, 1, 203-224.

OSEwSKA, E., Stala, J. (2010). Wskazania dotyczące pracy z osobą z niepełnosprawnością intelektualną, wynikające z Programu nauczania religii rzymskokatolickiej w przedszkolach i szkołach z 2010 roku. W: J. Stala (red.), Przestrzenie pracy socjalnej (s. 117-126). Tarnów: Biblos.

Rincon-Perez, T. (2011). Sakrament pokuty. W: P. MeJer (red.), Kodeks prawa kanonicznego. Komentarz (s. 719-743). Kraków: Wolters Kluwer.

SOBÓR WATYKAŃSKI II (1965). Deklaracja o wychowaniu chrześcijańskim 'Gravissimum educationis'.

Sosna, K. (2007). Przygotowanie do Komunii Świętej osób niepełnosprawnych umysłowo w świetle dekretu Quam singulari. W: J. STALA (red.), Eucharystia - pokuta i pojednanie w katechezie (s. 235-244). Kielce: Jedność.

Sosna, K. (2010). Jak przygotować młodzież z niepetnosprawnościa intelektualna do bierzmowania? Gniezno: Gaudentinum.

\section{PASTORALNO-TEOLOGICZNE PODSTAWY KATECHEZY SAKRAMENTALNEJ OSÓB Z NIEPEŁNOSPRAWNOŚCIĄ INTELEKTUALNĄ}

\section{Streszczenie}

Wychowanie w wierze jest niezbywalnym prawem każdego człowieka, a wiec także osób z niepełnosprawnością intelektualną. Jest ono realizowane przy współpracy trzech środowisk wychowawczych: rodziny, szkoły i parafii. Jego integralny element stanowi katecheza sakramentalna przygotowująca do sakramentów pokuty i pojednania, Eucharystii oraz bierzmowania. Taki rodzaj posługi głoszenia Słowa Bożego wobec osób z niepełnosprawnością intelektualną wynika nie tylko z konieczności przyjęcia przez ochrzczone osoby z niepełnosprawnością intelektualną sakramentów inicjacji chrześcijańskiej oraz sakramentu pokuty i pojednania, ale przede wszystkim $\mathrm{z}$ interpretacji kanonów Kodeksu prawa kanonicznego, opinii teologicznej oraz praktyki katechetyczno-pedagogicznej.

Słowa kluczowe: katecheza sakramentalna; wychowanie religijne; osoby z niepełnosprawnością intelektualną; spowiedź; Eucharystia; bierzmowanie. 


\title{
PASTORAL-THEOLOGICAL FOUNDATIONS \\ OF THE SACRAMENTAL CATECHESIS \\ OF PEOPLE WITH INTELLECTUAL DISABILITIES
}

\begin{abstract}
S u m mary
Education in faith is an inalienable right of every human being, including people with intellectual disabilities. It is implemented with the cooperation of three educational environments: family, school and parish. Its integral element is the sacramental catechesis preparing for the sacraments of penance and reconciliation, Eucharist and Confirmation. This kind of ministry of proclaiming the Word of God to people with intellectual disabilities results not only from the necessity for the baptized persons with intellectual disabilities to accept the sacraments of Christian initiation and the sacrament of penance and reconciliation, but above all from the canons' interpretation of the canonical code, theological opinion and catechetical and pedagogical practice.
\end{abstract}

Key words: sacramental catechesis; religious education; people with intellectual disabilities; confession; Eucharist; confirmation. 